\title{
BEHAVIOUR OF MUSCLE PROTEIN FRACTIONS OF BROILERS DURING FREEZING AND FROZEN STORAGE
}

\author{
R. R. Linko and O. E. NikKILÄ \\ The State Institute for Technical Research, Laboratory for Food Research and \\ Technology, Helsinki
}

Received August 15, 1963

Nowadays, broilers are to an ever-increasing extent marketed frozen by means of the "cold chain». If frozen, and then stored at a low temperature, broilers keep for a much longer time than if subjected to chilling alone. As regards microbiological changes, frozen storage should allow of them being kept indefinitely. However, limits are imposed by the harmful chemical changes which occur above all in fats and proteins. The rancidity of fats may currently be effectively prevented or retarded by suitable packaging, e.g. by application of the Cryovac method. Information on the changes which take place in the muscle proteins is still rather scanty. Nevertheless, it is upon the proteins that there depend such important properties as the tenderness, palatability and juiciness of the meat. These properties may be influenced in the growth phase of chickens by attention to suitable growing conditions, particularly with respect to nutrient composition. Also, the treatment of chickens before and after slaughtering is very important from the point of view of the quality of the product. Immediately after slaughtering, chicken muscles are soft, but they soon become progressively hard and rigid (the state of wrigor mortis»). The speed and strength of rigor changes depend on many factors, such as the temperature and the amounts of glycogen and energy-rich phosphorous compounds, creatine phosphate (CP) and adenosine triphosphate (ATP). In the state of rigor, meat is very tough. If, however, it is allowed to age in the chilling space, it gradually begins to become tender, and the state of rigor is resolved. Whereas the changes which occur at the onset of rigor (disappearance of glycogen, formation of lactic acid, a corresponding lowering of $\mathrm{pH}$, loss of ATP) are relatively well known, the changes involved in the resolution of rigor are still generally a matter for conjecture. Different 
authors have assumed that changes in connective tissue, dissociation of the main component of the muscle protein, actomyosin, and a rise in its solubility, an increase in the hydration of muscle proteins, or proteolysis, are responsible (for discussion, see 39$)$.

As regards chicken, only a few limited experiments have been made on the onset and resolution of rigor $(7,9,28)$. Furthermore, information or: the related question concerning the stage at which it would be most advantageous to freeze the broilers is rather contradictory. Thus, FitzGerald \& Nickerson (12) recommended keeping for 2-3 days; again, HANSON et al. (16) reported that there was no increase in the tenderness of breast meat 3 hours after death at $+1.7^{\circ} \mathrm{C}$, whereas the thigh continued to increase in tenderness up to 42 hours after death. Koonz et al. (23) found greater differences in the breast muscles than in those of the leg, and considered that the changes proceeded for up to 24 hours. Pool et al. (34) stated that most of the change in the tenderness took place within 4 hours, and that very little if any change occurred after 12 hours at $0^{\circ} \mathrm{C}$.

With respect to the effect of freezing on quality, and particularly on tenderness, but few published reports have been found. PooL et al. (34) state that tenderization arrested by freezing proceeds at about the normal rate on thawing, and that cutting up the carcass in the early post-mortem period has a slight toughening effect. They also mention that the aging period can potentially be imposed as well at the stage of chilling as frozen storage or thawing. The rapid rigor brought about by freezing and thawing in the pre-rigor state ("thaw rigor") causes, according to DE FREMERY $\&$ Pool (7), a significant increase in the toughness of excised chicken muscles. However, this increase can be partially reversed by aging for 24 hours in the thawed state. Shrimpton (35), on the other hand, reported that none of the young chickens stored frozen was tough, and concluded that if toughness is found, its presence is likely to have been attributable to adverse conditions during the bird's life. Prolonged frozen storage may result in identifiable changes, although raw chicken is one of the products which keep well at all freezing temperatures (18).

It consequently appears from the above that the effects of aging, freezing and frozen storage on the muscle proteins of broilers need further clarification. This question is of both theoretical and practical interest. It may be mentioned that chicken is a favourable object for the study of post-mortem changes, since the birds may be grown under controlled conditions with respect to breed, diet and other factors, and thus the material is rather homogeneous. Another point of advantage is that the post-mortem changes in chicken are rapid in comparison with those in beef, for instance, as has been pointed out by WeINBERG \& Rose (38).

It has been observed in experiments with fish, that during freezing and frozen storage there take place great changes in the solubility of the muscle proteins, above all in the myofibrillar proteins $(29,30,31,32)$. Such a loss in solubility is connected with a lowering of quality. If the solubility loss is only temporary, it may be related to rigor changes, but if it is irreversible, it may be referred to as denaturation of the proteins concerned (cf. 33). In this study, an investigation was made as to whether solubility changes in the muscle proteins of broilers occur during freezing and frozen storage. First of all, it was necessary to decide how to 
fractionate and analyse the proteins in question, and then to apply these methods to samples at different phases of aging and storage. In addition, the $\mathrm{pH}$ and waterbinding capacity were studied with a view to characterizing the properties of proteins, and organoleptic testing was used to check the general quality.

\section{Experimental}

Material. The subjects of experiment were 9-week-old White Rock broilers (average weight approximately $1 \mathrm{~kg}$ ) whose diet and other growing conditions had been controlled. The chickens, which had not been starved, were slaughtered in the ordinary way in an industrial processing plant, the operations being as follows: electrical stunning, scalding in water at $52^{\circ} \mathrm{C}$ for 5 minutes, wet feather picking, evisceration and washing. This treatment took approximately 30 minutes. Immediately afterwards, the carcasses were chilled by immersion in slush ice. In freezing experiments, the chilling time was usually 1 hour, following which the carcasses were allowed to drain on racks at $2^{\circ} \mathrm{C}$. In the normal course of processing, the broilers were then packed in Cryovac film and frozen overnight in an air blast tunnel at $-35^{\circ} \mathrm{C}$. In the experimental series reported here, the treatment and storage temperature varied, and are described separately in the different series.

\section{Fractionation of muscle proteins of broilers}

Methods. As starting material, fresh breast muscles were utilized after the broilers had been chilled for 1 hour. The fat, bones and connective tissue were removed, and the muscles were used for fractionation of the proteins and analysis of the nitrogen compounds.

The method of fractionation was the same as that which the authors had applied succesfully in the investigations of muscle proteins of fish $(29,30)$. The muscles were ground in a meat mincing machine, and the soluble proteins extracted from the ground mass with a Top Drive Macerator (Townson \& Mercer Ltd.) at $10000 \mathrm{rpm}$. the solvent being sodium chloride solution of ionic strength $\mathrm{I}=0.855$, buffered to $\mathrm{pH} 7.0$ with sodium bicarbonate ( 0.16 per cent). For $45 \mathrm{~g}$ muscle mass, $950 \mathrm{ml}$ salt solution was used, the extraction time was 5 minutes, and the temperature $0^{\circ} \mathrm{C}$.

Fractionation of the proteins was effected in accordance with the following scheme (Fig. 1).

In the analysis of the most important protein fractions there were determined the total $\mathrm{N}$ of the breast muscle of the broiler from the minced muscle, the soluble $\mathrm{N}$ in the muscle extract, the "myosin" $\mathrm{N}$ (= actomyosin $\mathrm{N}+\operatorname{myosin} \mathrm{N}$ ) in the fraction precipitated after dilution with water to $\mathrm{I}=0.085$, and the non-protein $\mathrm{N}$ in the filtrate after trichloroacetic acid precipitation (these fractions are specifically marked in the scheme). Nitrogen determinations were made by means of the Kjeldahl-Gunning-Arnold method (1) except for "myosin» $\mathrm{N}$, which was assayed in 


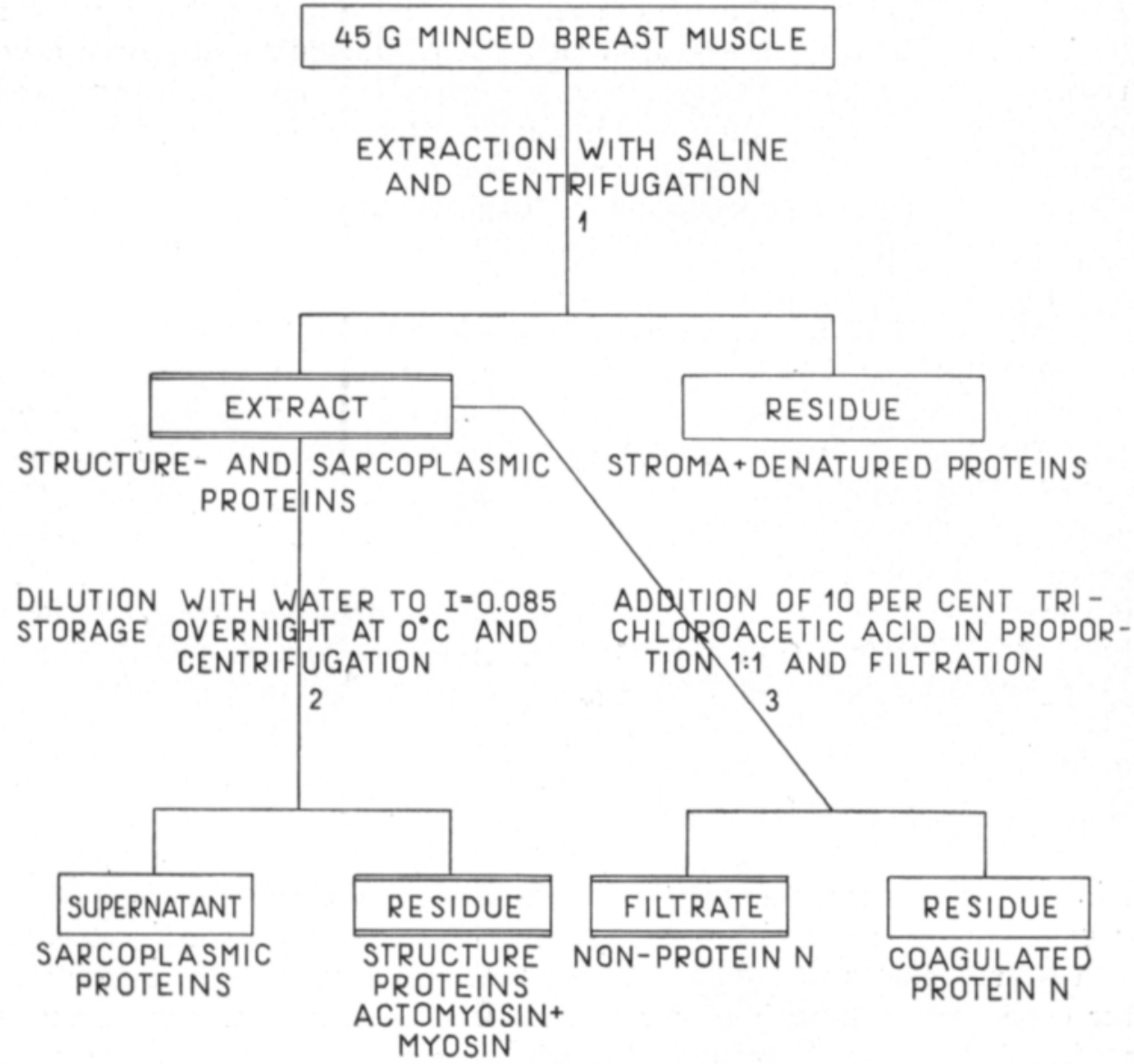

Fig. 1. Scheme for simplified fractionation of muscle proteins of chicken.

accordance with the micro-Kjeldahl method (2). The amounts of total protein N, soluble protein $\mathrm{N}$, sarcoplasmic protein $\mathrm{N}$ and stroma protein $\mathrm{N}$ were arrived at by difference.

Table 1. The results of the analyses, based on the mean of 16 samples.

Fractionation of proteins of breast muscle of broiler, and percentages of the most important proteins

\begin{tabular}{|c|c|c|c|}
\hline $\mathbf{N}$ fraction & $\mathrm{g} \mathrm{N} / 100 \mathrm{~g}$ & muscle & $\begin{array}{c}\text { per cent of total } \\
\text { protein } \mathrm{N}\end{array}$ \\
\hline Total N & $3.81 \pm 0.09$ & \pm 0.09 & \\
\hline Non-protein $\mathrm{N}$ & 0.52 & \pm 0.02 & \\
\hline Soluble N & 3.45 & \pm 0.18 & \\
\hline Total protein $\mathrm{N}$ (by difference) & 3.29 & & \\
\hline Soluble protein $\mathrm{N}(, \quad, \quad)$ & 2.93 & & 89.1 \\
\hline Myosin $\mathrm{N}$ & 1.94 & \pm 0.08 & 58.9 \\
\hline Sarcoplasmic protein $\mathbf{N}$ (by difference) & 0.99 & & 30.1 \\
\hline Stroma protein $\mathrm{N}$ (by difference) & 0.36 & & 10.9 \\
\hline
\end{tabular}


These results indicate that the extraction of soluble proteins, when using the macerator and saline $(\mathrm{I}=0.855, \mathrm{pH} 7)$ is accomplished quantitatively in a very short time. The condition is, however, that mixing of air into the homogenate is prevented by using a macerator of suitable construction (top drive macerator), along with the plate suggested by DyER et al. (10) below the surface of the solution. By this means, foaming and the resultant denaturation of proteins during extraction can be completely avoided, contrary to the opinions of Dingle et al. (8) and KHAN (20).

The amount of soluble protein in the breast muscle of normal, resting chickens, according to the present results, is on an average 89.1 per cent. Thus the calculated amount of insoluble residue (stroma) is approximately 11 per cent of the total protein. The amounts of "myosin" fraction and sarcoplasmic proteins in the breast muscle of 9 -week-old chickens, as assayed by this method, are respectively 59 and 30 per cent of the total protein. Of course, it also possible first to precipitate from the extract actomyosin at $I=0.25$, and then myosin at $I=0.08$, as has been done with chicken (20); WeINBERG \& Rose (38) used correspondingly $\mathrm{I}=0.225$ and 0.05 . However, it is frequently sufficient to analyse only the most important components, the "myosin" fraction and sarcoplasmic proteins, which can be assayed rather rapidly by application of the method reported above. Consequently, this method is well suited to following the changes in solubility which may occur in the muscle proteins of broilers during processing and frozen storage.

Very few results concerning the proportions of muscle proteins in broilers are available for comparison. KHAN (20), using chickens at the age of 4 months, obtained proportions of the myofibrillar, sarcoplasmic, and stroma proteins in the total protein $\mathrm{N}$ amounting to 54, 30 and 12 per cent respectively. These results are in rather close agreement with the present conclusions, particularly when there is borne in mind KHANs observation that with increasing age of the chickens, the amount of stroma protein also increases, whereas the myofibrillar protein decreases, and the proportion of sarcoplasmic proteins remains nearly constant. Thus, in the breast muscle of chickens the amounts of stroma proteins at the ages of 4 months and 1 year, calculated as above, are 12 and 16 per cent respectively. In this instance, the chickens were younger than those of KHAN and correspondingly the amount of stroma proteins was no more than 11 per cent, whereas that of the myofibrillar proteins was higher than KHANs figure, viz. 59 per cent.

\section{The effect of aging, freezing and frozen storage on the proteins of broilers}

If the methods employed in following the post-mortem changes are compared, it can be noted that organoleptic testing gives information on the changes in tenderness; after the rigor phase, during its resolution, tenderness gradually increases. Physical measurements, partícularly the evalution of toughness by measurement of shear force, are reported to be in close correlation with organoleptic testing. These methods have been those mainly used in the study of post-mortem changes in chicken. However, certain chemical analyses such as the determination of gly- 
cogen, ATP, lactic acid and $\mathrm{pH}$ have been employed for characterization of the rigor changes; these are suitable only in following the onset of rigor, since the changes which take place at this phase are not reversed during the resolution of rigor. This also applies with respect to the elastic properties of muscle; the loss of extensibility is not reversed when rigor is resolved. As regards the solubility of muscle proteins, the onset of rigor evidently implies a sharp decrease in buffer-extractable proteins, a fact probably connected with the lowering of $\mathrm{pH}$ to near the isoelectric point of both myosin and actomyosin (39). However, changes which occur in the solubility of the myofibrillar proteins during the resolution of rigor are less clear. In beef, it seems that the solubility of this protein fraction is not restored during tenderization (see 39). In chicken, where the resolution of rigor is more rapid than in beef, WEINBERg \& Rose (38) have found the solubility of myofibrillar proteins to be increased during aging. Nonetheless, no investigations have been made of the effect of freezing on the solubility of proteins. This is an important question when it is borne in mind that the freezing and frozen storage of fish cause a loss of solubility connected with quality losses. Another factor which has not been studied is the water-binding capacity in chicken muscle proteins. It has been stated (see 39) that factors such as tenderness, texture, drip on freezing and thawing, and shrinkage on cooking are all related to the degree of hydration of the muscle proteins. Consequently, it was deemed necessary to make an examination of the effects of aging, freezing and frozen-storage for different lengths of time on the solubility of the muscle proteins, on the $\mathrm{pH}$ and water-binding capacity. Simultaneous organoleptic testing was used as a control. However, the small amount of breast muscle in these young broilers made it impossible to obtain this information for the whole of the series. The employment of leg muscles for sensory analysis as was done by SHRIMPTON, was considered inadequate since the speed of tenderization of breast and leg muscles seems to differ (cf. 16, 37). As studies of the tenderness of chicken meat had earlier been made by organoleptic and physical methods in particular it was believed that the present investigation would provide complementary information with regard to questions not studied hitherto.

Methods. Protein fractionation and analysis were carried out in the manner described above. The water-binding capacity was determined according to the method of GRAU \& HAMM (13), by measurement of the amount of wfreen water ("lockeres Wassern), stated as a percentage of the total weight of the muscle. This amount is inversely proportional to the water-binding capacity. Grilled broilers were used for organoleptic testing.

The broilers were slaughtered in the way outlined above. The freezing of whole birds packed in Cryovac film was effected either immediately after slaughtering, without chilling (I), or after aging at $+2^{\circ} \mathrm{C}$ for 1 day (II), 2 days (III) or 6 days (IV). The freezing temperature was $-10^{\circ} \mathrm{C}$, and storage temperature also $-10^{\circ} \mathrm{C}$. The high temperature for freezing and storage was chosen by virtue of the necessary storage time being shortened as a result; such a so called maccelerated method" is nowadays currently used on studying the changes in quality which occur in frozen products (19). It is assumed that the changes of the quality in frozen products are approximately the same at high and low frozen storage temperatures, but that they 
occur earlier at the former. For instance, clearly discernible changes in chicken are to be found at $-10^{\circ} \mathrm{C}$ after some 200 days, whereas at $-20^{\circ} \mathrm{C}$ this occurs only after some 900 days $(18,22)$. Analyses of the samples which had been thawed in the package at room temperature for 5 hours (during this period, they had not completely thawed) were made after progressively increased periods of storage, viz. $0,1,4,7$, and 11 months at $-10^{\circ} \mathrm{C}$. The samples for organoleptic testing were thawed overnight at room temperature, and grilled for 50 minutes.

Results. Figure 2 presents the amounts of soluble protein $\mathrm{N}$ and "myosin" N. If we consider first the effect of aging before freezing (storage for 0 months) it is seen that the values vary but little. In soluble protein $\mathrm{N}$, the range is from 87.3 to 93.9 per cent (average 90.2 per cent) and in "myosin" $\mathrm{N}$ from 53.0 to 58.3 per cent (average 56.2 per cent). There is observable no progressive change connected with the length of aging, since the values are highest after aging for 0 and 6 days and lowest after 1 and 2 days. Thus the differences between the values are probably attributable to chance variations, perhaps the consequence of varying amounts of connective tissue (compare Ironside \& Love 1956). On comparison with the above reported corresponding average values for these fractions, it can be noted that the agreement is good; for soluble protein $\mathrm{N}$, average 89.1, here 90.2 per cent, for "myosin" $\mathrm{N}$, average 58.9 , here 56.2 per cent.

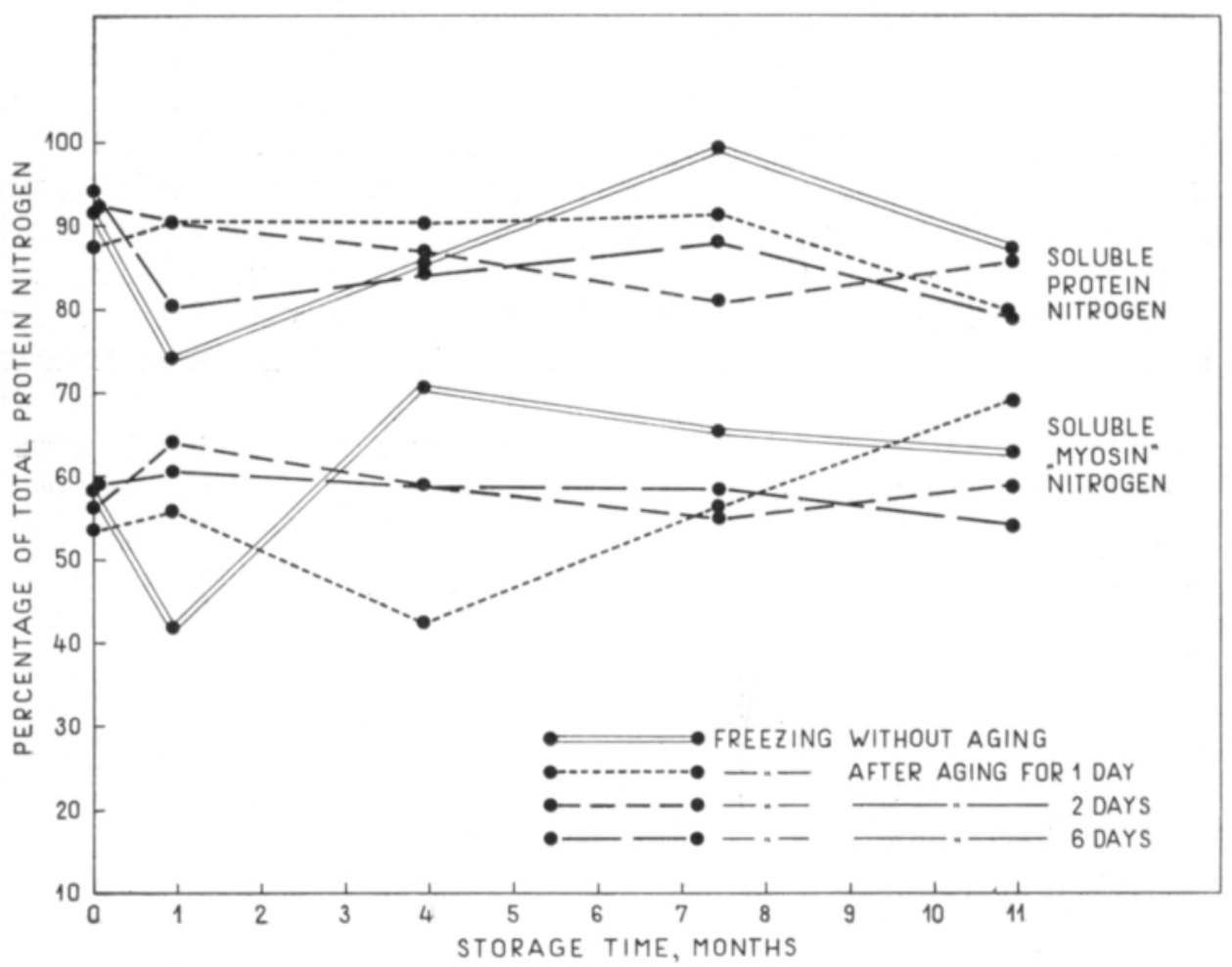

Fig. 2 Changes in soluble protein and "myosins in breast muscles of broilers during frozen storage, depending on the length of aging period. 
Secondly, the effect of frozen storage at $-10^{\circ} \mathrm{C}$ requires evaluation. A general feature is that the muscle proteins of broilers show no definite loss of solubility during frozen storage extending over 11 months, despite the rather unfavourable storage temperature. During this period, the amounts of "soluble protein" and extractable "myosin" fractions remained almost unchanged on the level of fresh chicken, except in specimens frozen immediately after slaughtering (I). In this last-mentioned case, the amount of extractable "myosin" had been abruptly reduced after 1 month of frozen storage. However, this change was reversible, as after 4 months storage the solubility of "myosin" was again restored, and even exceeded the original value. Against this, it may be mentioned that in fish the "myosin" fraction is the one in which occurs the loss of solubility during frozen storage (cf. 31).

The corresponding changes in water-binding capacity and $\mathrm{pH}$ in the breast muscle of broilers during the same period are presented in Table 2.

Table 2. Values of $\mathrm{pH}$ and free water in breast muscle of broiler, frozen $(I)$ immediately after slaughtering, or $(I I)$ after aging at $+2^{\circ} \mathrm{C}$ for 1 day, $(I I I)$ similar aging for 2 days or $(I V)$ for 6 days, after frozen storage at $-10^{\circ} \mathrm{C}$

\begin{tabular}{|c|c|c|c|c|c|c|c|c|}
\hline $\begin{array}{l}\text { Storage period, } \\
\text { months }\end{array}$ & $\mathrm{pH}$ & $\begin{array}{c}\text { free } \\
\text { water } \\
\text { per } \\
\text { cent }\end{array}$ & $\mathrm{pH}$ & $\begin{array}{c}\text { free } \\
\text { water } \\
\text { per } \\
\text { cent }\end{array}$ & $\mathrm{pH}$ & $\begin{array}{c}\text { free } \\
\text { water } \\
\text { per } \\
\text { cent }\end{array}$ & $\mathrm{pH}$ & $\begin{array}{c}\text { free } \\
\text { water } \\
\text { per } \\
\text { cent }\end{array}$ \\
\hline $\begin{array}{l}0 \text { (before } \\
\text { freezing) }\end{array}$ & 5.70 & 27.7 & 5.65 & 24.0 & 5.69 & 24.0 & 5.68 & 25.3 \\
\hline 1 & 5.72 & 37.4 & 5.70 & 37.1 & 5.70 & - & 5.70 & - \\
\hline 4 & 5.75 & 28.3 & 5.75 & 20.6 & 5.80 & 22.6 & 5.86 & 29.7 \\
\hline 7 & 5.70 & - & 5.73 & - & 5.90 & - & 5.75 & - \\
\hline 11 & 5.72 & 50.0 & 5.62 & 35.9 & 5.80 & 27.4 & 5.80 & 33.5 \\
\hline
\end{tabular}

This table shows that during the storage the $\mathrm{pH}$ of the muscle remained nearly constant, the limits being $\mathrm{pH} 5.70$ and 5.90. According to SHrimpton (35), the original $\mathrm{pH}$ of fresh chicken muscle before rigor is 7.05. De Fremery \& PooL (7) have stated that the rigor state is attained in the excised muscles of broilers of 10 to 16 weeks age at room temperature within $2-4 \frac{1}{2}$ hours after slaughtering, and that the $\mathrm{pH}$ of the muscle then reaches its ultimate value, $\mathrm{pH} \mathrm{5.8-5.9.} \mathrm{Against}$ this, Shrimptons experiments (35) showed that under the most usual processing conditions the state of rigor in the muscles of whole chickens is already reached 10 minutes after slaughtering. In any case, in our experiment with whole chickens the onset of rigor was completed, on the basis of the $\mathrm{pH}$ values, after the slaughtering treatment, the minimum duration of which was approximately 30 minutes; this result is in close accord with that reported by SHRIMPToN.

As regards the amount of sfreen water present in the fresh breast muscle of chicken, this was found to be greatest immediately after slaughtering (I); after aging at $+2^{\circ} \mathrm{C}$ for 1 day it was slightly less and during the course of aging for 6 days remained at nearly the same level. In freezing and frozen storage, the amount of "freen water first showed irregular fluctuations, but later, after 11 months storage, 
there was observable a rise of "freen water in all cases. This was at its peak (50 per cent) in chickens frozen without aging (I).

In conclusion, the water-binding capacity, which is inversely proportional to the amount of "freen water, is diminished after slaughtering (rigor mortis state), and also seems to decrease after prolonged frozen storage. It can be concluded from these results that aging is favourable for the water-binding capacity, but the difference between aging for 1 and 6 days seems insignificant.

In the organoleptic evaluation, it was found that those broilers not allowed to age were rubbery and tough in consistency, both immediately after slaughtering and after frozen storage for 1 month. In contrast, aged broilers were all tender at the corresponding phases, i.e. before freezing and after 1 month's storage. No differences which could be ascribed to the length of the aging period were found in the degree of tenderness between these broilers subjected to aging.

On the basis of the $\mathrm{pH}$, it is evident that broilers which were not aged had already been in the rigor state before freezing. As a consequence, the meat of such broilers was tough. If these broilers were additionally frozen, stored for 1 month, and thawed, no definite tenderization had occurred during these phases. Accordingly the tenderization achieved in all the other series was due to the aging.

Published reports contain some observations on the possibility of changes taking place during frozen storage. According to PARTMAnN (33) the splitting of energy-rich nucleotides (e.g. ATP) in chicken muscle is completed at $-8^{\circ} \mathrm{C}$ in $10-25$ days, whereas at $-24^{\circ} \mathrm{C}$, after 6 months, $70-100 \%$ of the initial ATP content is still present. Thus completion of the onset of rigor may take place even in the frozen state, with the speed dependent on the storage temperature. Tenderization in the frozen state may also occur. Pool et al. (34) reported that although no appreciable tenderization in chicken took place in frozen carcasses at $0^{\circ} \mathrm{F}(=$ $-18^{\circ} \mathrm{C}$ ) over a 4 month period, significant tenderization occurred at $25-27^{\circ} \mathrm{F}$ $\left(=-2--4^{\circ} \mathrm{C}\right)$ when they were kept for several days. In the present instance, the temperature was lower than in the last-mentioned case; thus no definite tenderization had occurred in 1 month at $-10^{\circ} \mathrm{C}$.

The results of organoleptic testing seem to agree with the information found in literature (cf. survey by PooL et al. 34).

\section{Discussion}

If the results obtained are put into perspective with earlier practical experience in the field, organoleptic evaluation should be considered first. It appears that studies have been principally concerned with the effect on the tenderness of treatment before freezing, but the effect of frozen storage is not so clear. The present finding, that aged broilers were all tender agrees, for instance, with the results obtained by SHRIMPTON (35), that only tender broilers were obtained when the aging period before freezing had been at least 2 hours. By contrast, freezing without aging here gave tough meat, both before freezing and after frozen storage for 1 month. This agrees with the result of Lowe (25), that chickens frozen within 2 hours after 
killing were less tender than those aged for 24 hours before freezing. Hanson et al. (16) have pointed out that even if the meat is put in the oven only 6 minutes after killing, rigor develops during cooking; in such event the muscles are extremely tough. The toughness of the muscles found immediately after slaughtering in the present experiments is in agreement with earlier experience. Little information is available on the effect of frozen storage, and results seem to be contradictory. According to STEWART et al. (36), the difference between fresh and frozen broilers becomes highly significant after 51 days of storage, although the least favourable storage temperature was $-20.5^{\circ} \mathrm{C}$. JuL (18) has pointed out that raw chicken keeps well at all freezing temperatures, as judged by organoleptic means. PooL et al. (34) assume that freezing essentially arrests any changes which would otherwise occur during that period. The present results provide no additional information on organoleptic changes during prolonged storage.

If the results arrived at are considered in the light of earlier information on the rigor phases in chicken, it seems clear, to judge from the tenderness, that the breast muscles have passed through rigor after 24 hours aging. This closely agrees with earlier experience. Opinions held on the exact time of rigor seem to vary. In the present results, the different methods employed to characterize the rigor phase display some curious features. In the series without aging, the agreement between the different results was good after 1 month's frozen storage: the toughness of muscles in the organoleptic test, the decreased solubility of "myosin», and the low water-binding capacity. By contrast, the results diverge before freezing, the meat was very tough in the organoleptic test, and the $\mathrm{pH}$ was low, indicating a state of rigor mortis, but the solubility of mmosin» was good and the water-binding capacity higher than after freezing and frozen storage. The explanation of this strange result may perhaps be that grilling before organoleptic testing may have promoted the rigor, resulting in toughness (cf. 16). Although the $\mathrm{pH}$ had already reached its ultimate value, it may be possible that the solubility of "myosin», which was assayed as quickly as possible, had not yet been lost, and similarly the water-binding capacity was still rather high. The method of "myosin" assay includes very effective solubilization by virtue of the mechanical homogenization, which may also partially explain this result. In addition, it should be mentioned that the onset of rigor seems to proceed with different speed in excised muscles - according to De FREMERY \& POOL (7) rigor occurs $2-4 \quad 1 / 2$ hours after death - and in whole carcasses it is more rapid, and may even occur after 10 minutes (35); here, for organoleptic testing the chickens were treated whole, whereas the muscles were excised for assay of the solubility of "myosin".

A comparison with literature shows the following. WEINBERG \& Rose (38) observed that the solubility of "myosin» was low if analysed within 30 minutes from death, and higher 24 hours later. Van den BERG et al. (37) found that during chilled storage, the solubility of "myosin» in breast muscle aged for 18 - 20 hours remained unchanged at a high level for 5 weeks, but they noted an increase in the solubility in thigh muscle during the early part of such storage. The authors thus concluded that tenderization of leg meat is related to the increase in protein extractability during the first week of storage. It seems, then, that the increase in the solubility 
of "myosin" is a characteristic feature in post-mortem tenderization in chicken, in contrast to the poor correlation of these factors in beef. A similar trend was observed in the present results, although the occurrence of the loss in solubility owing to the onset of rigor was somewhat delayed. It is particularly interesting to note that no loss of solubility was observable during prolonged storage, a result confirmed by similar observations of van den BERG et al. as far as aging is concerned, whereas no results as regards frozen storage are available for comparison. It may be emphasized that in the present experiments the conditions of frozen storage were made purposely unfavourable. Nevertheless, no definite loss in solubility of "myosin" occurred during 11 months, irrespective of the length of aging of the chickens before freezing. This is in sharp contrast to the findings with respect to fish, studied earlier by the authors $(29,30,31,32)$, but in agreement with the statement of JuL (18) that raw chicken keeps well at all freezing temperatures. However, the present results show that the water-binding capacity of breast muscles is diminished after 11 months of frozen storage.

The special feature of the structure proteins in fish is that their association in muscle is much looser than in homoiothermic animals. This is shown, for instance, in the ease of extraction of tropomyosin and actomyosin from fish muscles as compared with the corresponding proteins of rabbit $(14,15)$. Conversely, it is more difficult to extract pure myosin from fish muscle than from the muscles of warmblooded animals (15), since the extractants remove myosin and actin together from the fish muscle, and these proteins combine in the extract to form actomyosin (6). This loose structure of the fish muscle may also cause the great lability of the structure proteins and their susceptibility to various external factors. The current experiments emphasize the different stability of structure proteins in various classes of animals.

\section{$S u m m$ ary}

A method has been introduced for the analysis of protein fractions in chicken, in analogy with similar fractionation used for fish muscle proteins. The percentage figures for the most important protein fractions in the breast muscle of 9-week-old broilers were found to be: sarcoplasmic protein 30 , "myosin» 59, giving a total of soluble proteins of 89 , and stroma proteins 11 per cent.

This method was applied to follow possible changes in the solubility of "myosin" during post-mortem aging and subsequent freezing and frozen storage. At the same time, there were determined the $\mathrm{pH}$ and water-binding capacity. Organoleptic evaluation was used as a check.

It was found that the solubility of "myosin» was lowered only in broilers frozen without aging, after 1 month of storage. Simultaneously, water-binding capacity was lowered, and the meat proved tough by organoleptic test. Prolonged frozen storage, by contrast, caused no loss in solubility of "myosin". The water-binding capacity was lowered after prolonged storage, particularly in broilers frozen without aging. 


\section{REFERENCES}

(1) A.O.A.C. 1949. Methods of Analysis, 6th ed. p. 27 The Colleginte Press, Menasha, Wisconsin.

(2) A.O.A.C 1949. Methods of Analysis, 6th ed. p. 763. Ibid.

(3) Вате-Sмгтн, E. C. 1939. Changes in elasticity of mammalian muscle undergoing rigor mortis. J. Physiol. 96: 176.

(4) Bate-Smith, E. C. \& Bendall, J. R. 1947. Rigor mortis and adenosine triphosphate. Ibid. 106: 177.

(5) Bendall, J. R. 1951. The shortening of rabbit muscle during rigor mortis: its relation to the breakdown of adenosine triphosphate and creatine phosphate and to muscular contraction. Ibid. 114: 71.

(6) Connell, J. J. 1958. Studies on the protein of fish skeletal muscle. Biochem. J. 69: 5.

(7) de Fremery, D. \& Pool, M. F. 1960. Biochemistry of chicken muscle as related to rigor mortis and tenderization. Food Res. 25: 73-87.

(8) Dingle, J. R., Eagles, D. E. \& Neelin, J. M. 1955. Electrophoretic studies of proteins extractable from post-rigor cod at low ionic strength. J. Fish. Res. Board Can. 12: 75.

(9) Dodge, J. W. \& Stadelman, W. J. 1959. Post Mortem Aging of Poultry Meat and its Effect on the Tenderness of the Breast Muscles. Food Technol. 13: 81-84.

(10) Dyer, W. J., French, H. V. \& Snow, J. M. 1950. Proteins in fish muscle. I. Extraction of protein fractions in fresh fish. J. Fish. Res. Board Canada 7: 584 .

(11) ERDös, T. 1943. Rigor, contracture and ATP. Studies Inst. Med. Chem. Univ. Szeged 3: $51-56$.

(12) Fitzgerald, G. A. \& Nickerson, J. T. R. 1939. Effect of time and temperature of holding undrawn poultry upon its quality. Proc. 7th World's Poult. Congr. (Cleveland, Ohio): 509-512.

(13) Grav, R. \& Намм, R. 1952. Eine einfache Methode zur Bestimmung der Wasserbindung in Fleisch. Die Fleischwirtsch. 4: 295-297.

(14) Guba, F. 1943. Studies Inst. Med. Chem. Univ. Szeged 3: 40.

(15) Hamoir, G. 1955. Fish protein. Advances in Protein Chem. 10: 227.

(16) Hanson, H. L., Stewart, G. F. \& Lowe, B. 1942. Palatability and histological changes occurring in New York dressed broilers held at $1.7^{\circ} \mathrm{C}\left(35^{\circ} \mathrm{F}\right)$. Food Res. 7: 148-160.

(17) Ironside, J. I. M. \& Love, R. M. 1956. Measurement of denaturation of fish protein. Nature (London) 178: 418-419.

(18) JUL, M. 1961. Calculating the keeping quality of frozen foods. Food Manuf. 36/12: 520-526.

(19) JuL, M. \& Dalнoff, E. 1961, Metode til beregning of frysevarers holdbarhed. Kulde 15: 1-7 and $18-19$.

(20) Кнал, A. W. 1962. Extraction and Fractionation of Proteins in Fresh Chicken Muscle. J. Food Sci. 27: $430-434$.

(21) Klose, A. A., Pool, M. F., Campbell, A. A. \& Hanson, H. L. 1959. Time-temperature tolerance of frozen foods. XIX. Ready-to-cook cut-up chicken. Food Technol. 13/9: 477-484.

(22) Kondrup, M. 1961. Tid-temperatur-forhold i distributionen af dybfrosne varer. M-2-5 Fr y s ev a r e r Manuskript nr 155 (udarbejded for Nordisk Kølemøde, Helsingfors, august 1951, pp. 1: 12.

(23) Koonz, C. H., Darrow, M. I. \& Essary, E. O. 1954. Factors influencing tenderness of principal muscles composing the poultry carcass. Food Technol. 8: 97.

(24) Lawrie, R. A. 1953. The onset of rigor mortis in various muscles of the draught horse. J. Physiol. (London) 121: 275 .

(25) LowE, B. 1948. Factors affecting the palatability of poultry with emphasis on histological postmortem changes. Advances in Food Res. Vol. 1: 203.

(26) Marsh, B. B. 1952. Observations on rigor mortis in whale muscle. Biochem. et Biophys. Acta $9: 127$.

(27) - - 1954. Rigor mortis in beef. J. Sci. Food Agr. 5: 70.

(28) May, K. N., Saffle, R. L., Downing, D. L. \& Powers, J. J. 1962. Interrelations of Post-Mortem changes with Tenderness of Chicken and Pork. Food Technol. 16: 72-78.

(29) NіккіLÄ, O. E. \& Linко, R. R. 1954. Denaturation of myosin during defrosting of frozen fish. Food Res, 19: 200-205. 
(30) NikkiLÄ, O. E. \& LiNko 1954. Denaturation of myosin in fish muscle and in myosin sol by salts. Suomen Kemistilehti B 27: $37-42$.

(31) $--\&--1956$. Freezing, packaging and frozen storage of fish. Food Res. 21/1: $42-46$.

(32) NıккıLĀ, O. E. 1957. Om förändringar i myosinfraktionen ur fiskmuskel vid nedfrysning, fryslagring och upptining. Nordisk Kjølemøte 1957, Bergen, p. $108-116$.

(33) Partmann, W. 1963. Post-mortem changes on chilled and frozen muscle. J. Food. Sci. 28/1: $15-27$.

(34) Pool, M. F., de Fremery, D., Campbell, A. A. \& Klose, A. A. 1959. Poultry tenderness. II. Influence of processing on tenderness of chickens. Food Technol. 13: 25-29.

(35) Shrimpton, D. H. 1960. Some causes of toughness in broilers (young roasting chickens) I. Packing station procedure, its influence on the chemical changes associated with rigor mortis and on the tenderness of the flesh. Brit. Poultry Sci. 1: 101-110.

(36) Stewart, G. F., Hanson, H. L., Lowe, B. \& Austin, J. J. 1945. Effects of aging, freezing rate, and storage period on palatability of broilers. Food Res. 10: 16-27.

(37) van den Berg, L., Khan, A. W. \& Lentz, C. P. 1963. Biochemical and quality changes in chicken meat during storage at above-freezing temperatures. Food Technol. 17/1: 91-94.

(38) Weinberg, B. \& Rose, D. 1960. Changes in protein extractability during post-rigor tenderization of chicken breast muscle. Fcod Technol. 14: 376-379.

(39) Whitaker, J. R. 1959. Chemical changes associated with aging of meat with emphasis on the proteins. Advances in Fcod Research IX, 1959, 1-60. New York and London, edited by C. O. Chichester, E. M. Mrak and G. F. Stewart.

\title{
SELOSTUS
}

\section{MUUTOKSET KANANPOJAN LIHASPROTEIINEISSA PAKASTUKSEN JA PAKKAS- VARASTOINNIN AIKANA}

\author{
R. R. Linko ja O. E. NıккILÄ
}

Valtion teknillinen tutkimuslaitos, Elintarvikelaboratorio, Helsinki

Kanan proteiinifraktioiden analysoimiseksi sovellettiin menetelmää, joka vastaa kalan lihasproteiinien analyysissä käytettyä. Tällä menetelmällä saatiin 9 viikon ikäisten kananpoikien rintalihaksen tärkeimmille proteiinifraktioille seuraavat arvot: sarkoplasmaproteiinia $30 \%$ ja $»$ myosiinias $59 \%$, eli yhteensä $89 \%$ liukoista proteiinia. Loput $11 \%$ on stroomaproteiinia.

Tätä menetelmäă käyttäen seurattiin smyosiinins liukoisuudessa mahdollisesti tapahtuvia muutoksia teurastuksen jälkeisen riiputuksen ja sitä seuraavan pakastuksen ja pakkasvarastoinnin aikana. Samalla määritettiin $\mathrm{pH}$ ja vedensitomiskyky. Organoleptistä arvostelua käytettiin kontrollimenetelmänä.

Voitiin todeta, että mmyosiinin» liukoisuus oli alentunut ainoastaan sellaisilla kananpojilla, jotka pakastettiin ilman riiputusta, kuukauden pakkasvarastoinnin jälkeen. Samanaikaisesti oli vedensitomiskyky alentunut, ja organoleptisessä arvostelussa liha todettiin sitkeäksi. Sensijaan pitkä pakkasvarastointi ei aiheuttanut ımyosiininı liukoisuudessa alenemista. Pitkä pakkasvarastointi huononsi vain vedensitomiskykyä erikoisesti silloin, kun pakastaminen tapahtui ilman riiputusta. 